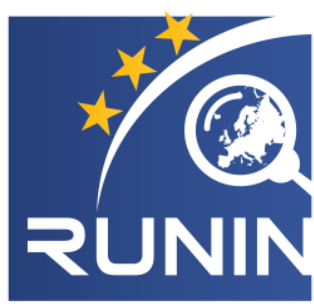

The Role of Universities in Innovation and Regional Development

\title{
Creating Bridges between Corporate Governance and Innovation
}

WORKING PAPER 07/2018

\section{Serglo Manrlque}

Department of Business - Universitat Autònoma de Barcelona

SergioAndres.Manrique@uab.cat 


\section{Abstract}

The issues studied by the corporate governance research stream, such as control and ownership structure, board composition, monitoring mechanisms and shareholders' protection, among others, seem not to relate to further matters examined by other research streams in the fields of innovation and regional studies, despite they all can fit in the business and economics subject and, furthermore, they all make part of the social science discipline. Phenomena such as regional innovation systems and university-firm collaboration, which innovation studies have taken care of so far, are influenced by the governance and control of firms and institutions; additionally, the dynamics among different stakeholders (firm managers, investors, institutions, etc.), in terms of corporate governance and innovation, have a relevant impact on firms and regions. This paper attempts to explore the links between these two research streams, considering a more holistic view of their interest matters, in order to better understand how they jointly influence firm performance and regional development. This is an exploratory and introductory piece of research that aims to discuss the links between corporate governance and innovation, exploring valuable ideas and matters to be more deeply studied in future research.

Keywords: Corporate Governance, Innovation, University-Firm Collaboration, Entrepreneurship, Regional Development.

JEL: I23; G30; L20; O10; O30; R58

This paper was presented for assessment in the Erasmus+ Jean Monnet Summer School on "Corporate Governance and European Integration", which took place at the Faculty of Economics, University of Ljubljana, Slovenia on July 10 $0^{\text {th }}-14^{\text {th }} 2017$. 


\section{Table of Contents}

1. Introduction

2. Traditional research overview............................................................................................... 6

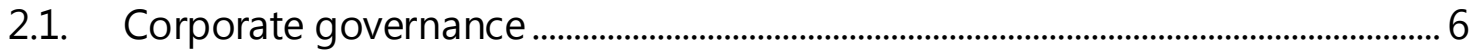

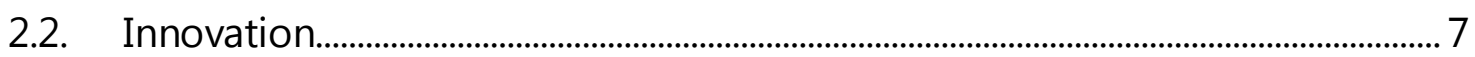

2.3. Traditional linkage .......................................................................................................

3. Building bridges between corporate governance and innovation .......................... 9

3.1 The basics of connecting governance and innovation...............................................

The Governance of Innovation..................................................................................................... 9

Innovation in Governance .........................................................................................................

3.2 Corporate governance and entrepreneurship..............................................................11

3.3 The governance of universities …………………………………………………………......12

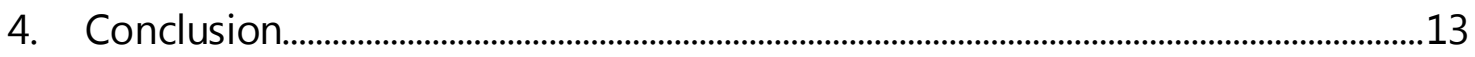

Acknowledgements ..................................................................................................................13

5. References.............................................................................................................................13 


\section{Creating Bridges between Corporate Governance and Innovation}

\section{Introduction}

The over-examination of traditional issues, as well as the hunt of contrasting results and different methods based analyses, have been accompanied by severe criticism on the reliability and validity of social science research. Bias on methods and analysis, omission of results and low data transparency, among others, make part of the criticised matters that have caused the introduction of new policies for data accessibility, replication and transparency in the submission and review processes of top journals (Tsui, 2013). This is a relevant issue for future research, which must find a way to generate credible knowledge responsibly, through the search of unexamined and novel issues rather than the application of different methods and techniques on sufficiently studied topics, which can lead to low explanatory power, non-replicable findings and lack of useful ideas and discussions. Unlike natural science research, which can have strong, replicable and persistent findings based on empirical evidence, social science research counts with a big dose of nondeterministic factors which must be taken care of when analysing its results and discussing its findings. In business studies, for instance, there is not a unique equation or set of explanatory variables for determining the performance and competitiveness of a firm, even in each specific context; however, research on business and management can lead to better understand the behaviour of firms and industries and to reveal the determinants of their past performance; and this information can be used to shape more suitable future strategies. This situation can also be observed in other disciplines within social science, such as regional studies with the study of economic growth and social development at regions, or microeconomics with the study of supply and demand in markets.

With the evolution of the European Union, the integration of economic practices has influenced the dynamics of firms and regions at both micro and macro levels, and this has affected the development of corporate governance and innovation in businesses. The cohesion policy of European Commission aims to reduce economic and social gaps among EU member states, promoting a more balanced and more sustainable territorial development; in practice, this has translated into hundreds of thousands of projects all over Europe, with several governments, firms and universities, among others, receiving funding in order to enhance the cohesion and integration of regions and countries in Europe. The corporate governance systems 
have also evolved in terms of unified schemes of board composition and shareholders' protection, for instance, at both national and regional levels. At the same time, innovation at the firm level has lost relevance in comparison to the conception of regional innovation systems and its impact on development.

A suitable option for achieving useful ideas and discussions from responsible research is to explore the connections among different fields and disciplines, generating links among different research streams, such as corporate governance and innovation. The corporate governance research stream has traditionally examined issues such as control and ownership structure, board composition, monitoring mechanisms and shareholders' protection, among others, which seem not to relate to further matters examined by other research streams in the fields of innovation and regional studies, despite they all can fit in the business and economics subject and, furthermore, they all make part of the social science discipline. On the other hand, phenomena such as regional innovation systems and university-firm collaboration, which innovation studies have approached so far, are influenced by the governance and control of firms and institutions; additionally, the dynamics among different stakeholders (firm managers, investors, institutions, etc.), in terms of corporate governance and innovation, have a relevant impact on firms and regions.

This work attempts to explore the connections between these two research streams, generating links that could be potentially studied in future research. Additionally, it seeks to examine the possible determinants of firm performance and regional development from a more holistic view that integrates corporate governance and innovation issues. This is an exploratory and introductory study indeed, whose goal is to discuss future research opportunities which can be interesting and useful for practitioners and policy makers. This paper is structured as follows: Next section (2) presents the most visited issues of research on corporate governance and innovation individually; then, (3) possible matters connecting these two research streams are discussed; after that, a section is dedicated to (4) the role of European integration in the link of corporate governance and innovation studies; finally, (5) some final remarks are presented, including an overview of future research opportunities. 


\section{Traditional research overvlew}

A first necessary step before exploring more novel issues is taking a general look at the traditionally researched issues in the streams of corporate governance and innovation. This section also presents an overview of the typically visited topics in the past attempts to link these two fields.

\subsection{Corporate governance}

The corporate governance research stream generally studies the relations and processes by which firms are controlled and governed; the governance of businesses/firms, apart from seeking productivity and maximizing profits, must take care of the interests of firm stakeholders and deal with principal-agent conflicts present at corporate level (shareholders-CEO, manager-employees, etc.). As indicated by a very popular survey on corporate governance research (Shleifer \& Vishny, 1997), this research stream has traditionally visited issues such as legal protection of investors and ownership concentration in corporate governance systems around the world. Per the Cadbury Report and the Organization for Economic Cooperation and Development, the corporate governance principles in a firm could be synthetized in: 1) rights and equitable treatment of shareholders, 2) interests of other stakeholders, 3) role and responsibilities of the board, 4) integrity and ethical behaviour and 5) disclosure and transparency (Cadbury, 1992; OECD, 2004).

Additional to the legal rules covering protection of corporate shareholders and creditors, corporate governance research stream has examined the origin of these rules, and the quality of their reinforcement in different countries with different law systems: common-law countries, French-civil-law countries, German- and Scandinavian-law countries, in where the relationship between investor protection and ownership concentration has been studied (La Porta et al., 1998). Studies commonly come up with conclusions indicating a stronger investor protection in common-law countries and a weaker one in civil-law countries, as well as a negative relationship between concentration of ownership of shares and investor protection. 
The relationship between certain corporate governance characteristics and firm performance (profitability) has also been widely examined, and the most supported hypothesis established that firms with stronger shareholders' rights tend to have higher firm value and higher profits (Gompers et al., 2003). Further matters of corporate governance such as corporate control, regulation, behavioural issues, the role of stakeholders (corporate social responsibility), board gender composition and firm performance, among others, have also been widely studied within this research stream (Goergen, 2012).

\subsection{Innovation}

At the firm level, innovation has been studied from different perspectives. One of these relevant views considers the capacity of firms to learn, stating that "the ability of a firm to recognize the value of new, external information, assimilate it, and apply it to commercial ends is critical to its innovative capabilities" (Cohen \& Levinthal, 1990). The innovative capabilities of a firm are expected to lead to better performance, due to the development and improvement of processes and products, however, this doesn't necessarily happen this way as other more complex factors such as market positioning and business strategy appear in scene (Teece, 1986). Going beyond the micro level, more importance has been given to innovation when considering a regional perspective, as the innovative capabilities of a region or country seem to be important for its development and economic growth; that is why the concept of the so called regional innovation systems has gained strength in regional studies (Cooke et al., 1997), considering the institutional and organizational dimensions of innovation at regions.

A way of studying (modelling) an innovation system in any given region is through the analysis of the interests and interaction among firms, universities, governments and citizens (quadruple helix model of innovation), as the four key actors in the innovation and development of regions (Arnkil et al., 2010). The European Union recognised the importance of research and innovation for economic growth and social welfare with the introduction of the Horizon 2020 programme (European Commission, 2017), in which the higher education institutions take a key role in innovation and regional development (Charles, 2006). Consequently, the role of universities in societies has evolved from a two-dimensional perspective (education 
$\&$ research) to a wider approach in which universities need to engage in activities related to innovation and regional development (Göransson \& Brundenius, 2011). That is why many universities around Europe have started to dedicate strong efforts to enhance their relationship with industry, which has transformed the orientation and the agenda of research activities at higher education institutions (Perkmann \& Walsh, 2007). University-industry interaction, as a matter related to both governance and innovation at firms and higher education institutions, can serve as a tool for generating impact on the development of regions where the interaction takes place (Manrique, 2017). University-firm collaboration seems to matter to both universities and firms as relevant benefits can be gained by both parts in a win-win relationship. Universities might enhance their third mission and enhance their impact on industries and on the economics of regions by collaborating with firms, which also leads to a better understanding of work market and commercial world for the improvement of education and research, as well as the dissemination of knowledge. Additionally, in the case of firms, apart from accessing internships programs, knowledge transfer and industrial theses, businesses would improve or create processes and products/services for gaining an improved performance in a global and competitive market.

\subsection{Traditlonal Ilnkage}

Despite highly unexplored, there has certainly been research linking corporate governance and innovation. These studies have frequently focused on the role of certain corporate governance features in the innovativeness of firms and regions, as well as on the effects of some governance characteristics, such as ownership structure or board composition, on firm performance/competitiveness. Hitt et al. (1996), for instance, analyses how acquisitions and divestitures, as corporate control mechanisms at the market level, affect internal control mechanisms and, together, influence internal and external innovation at firms. They found that external and internal control mechanisms do affect innovation processes in corporations, as firms engaging in acquisitions and divestitures, which also emphasize financial controls, tend to produce less internal innovation and, in turn, seek external innovation for gaining short term benefits. Moving to another corporate governance spectrum, the impact of ownership concentration on the innovation rates and economic growth of firms has also been examined (Morck et al., 2005), finding that family firms, mostly common outside USA and UK, tend to 


\section{Creating Bridges between Corporate Governance and Innovation}

suffer economic entrenchment and distorted property rights protection, which leads to negative effects on firm innovativeness.

Innovation strategies at firms are affected by governance features like institutional ownership heterogeneity (public vs private) and the profiles of boards' directors (outsiders vs insiders). In this sense, Hoskisson et al. (2002) indicate that in the case of funds, the acquisition of external innovation is more preferred in the case of professional investment funds in opposition to the development of internal innovation, more preferred by managers of public pension funds, which are also more likely to have inside directors in their boards. As the different studies mentioned represent, the relationships between governance characteristics and innovation at corporations, and between corporate governance and corporate performance, have been quite examined.

\section{Bullding brldges between corporate governance and Innovation}

Having covered the most relevant and studied issues that tried to link corporate governance and innovation, it is time to move to more unexplored matters which will allow to create new bridges between these two research streams.

\subsection{The basics of connecting governance and Innovation}

Two basic issues also present in past research, but relatively much less studied, are the governance of innovation itself, and innovation in governance.

\section{A. The Governance of Innovation}

As corporate processes, usually missional or strategic, innovation and R\&D imply decision-making, monitoring and dealing with stakeholders' interests; therefore, it should also be studied how innovation is governed and controlled at organizations. Moreover, regional innovation systems and quadruple helix model, mentioned before, have allowed to recognise the importance of governance in the innovation processes at regional level (Heidenreich \& Koschatzky, 2011). The design and implementation of innovation policy in (entrepreneurial) regional innovation (eco) systems might require a formal and flexible active 'agency' approach from different 
regional stakeholders (e.g. universities, local authorities, firms), expressed in terms of a process of constructive dialogue that allows the development of adaptable and realistic (regional) strategies aimed at boosting innovation and development in regions (Nieth et al., 2018). In this sense, higher education institutions, who have to deal both with their missions (e.g. internationalisation, research excellence) and with their relationship with external stakeholders, have become key stakeholders in the process of decision-making and negotiation of matters related to innovation and development at regions and firms (Manrique \& Nguyen, 2017). This role is especially relevant in peripheral and less-developed regions, where existing universities, beyond acting as producers and disseminators of knowledge (traditional missions), should engage in regional innovation systems in order to strengthen these regions' institutional landscape (Fonseca \& Cinar, 2017). In brief, universities 'third mission' includes engagement and active participation in the governance of regional innovation at an institutional level.

Technological regimes in different sectors affect the demands of innovation on the financial and corporate governance systems, which are faced differently among countries and regions. "A country's finance and corporate governance system is a key element of its national system of innovation" (Tylecote, 2007). In a contextbased perspective, matters such as property rights' legal protection, patenting/licencing rules and procedures and regional technology and infrastructure might affect the innovation of firms and regions. On the other hand, in a firm-based perspective, the board composition and ownership structure of a company also might affect the innovation of firms. These two perspective are governance-related and should be considered for analysing the drivers and determinants of innovation at micro and macro levels.

\section{B. Innovation In Governance}

Research on innovations in governance practices, both theoretically and empirically, deserves greater attention because it can generate useful knowledge for firms and public institutions in terms of decision-making, financing and production systems. So far, innovation literature has focused on the improvement of organizational performance through the innovation of products and processes, and the governance literature has focused on social coordination without drawing 
on innovation literature (Moore \& Hartley, 2008). It would be a good idea to examine innovations which seek to improve social performance through reorganizations of cross-sector decision-making, financing and production systems, especially in the case of the public sector. It would allow to tap new pools of resources and exploit government's capacity to shape private rights and responsibilities. Political governance, as a dimension of social innovation, is a key element for fostering inclusive development processes at societies because innovative governance arrangements have emerged as pathways towards greater equity among and within regions, challenging traditional state-centred forms of policy design (Swyngedouw, 2005).

Furthermore, in the case of firms, the evolution of corporate governance models at region and country level, in terms of changes in legal and institutional frameworks, has raised a need for adaptation from firms. Corporate governance reforms (an institutional innovation expression) have emerged in countries like Japan, generating the possibility of hybrid corporate governance systems (Yoshikawa et al., 2007). Changes and reforms in corporate governance systems, as well as the development of new governance practices within firms, are worth examination.

\subsection{Corporate governance and entrepreneurshlp}

A relevant issue that is worth considering is how can corporate governance influence entrepreneurship and growth of new firms, as corporate entrepreneurship is important for organizational survival, profitability, growth, and renewal. Past research has come with interesting findings about the effect of ownership features on corporate entrepreneurship (Zahra, 1996), indicating that executive stock ownership and long-term institutional ownership are positively associated with such entrepreneurship, however, short-term institutional ownership is negatively associated with it. Additionally, it has been observed that industry's technological opportunities moderate the relations observed between corporate governance (ownership) and corporate entrepreneurship. Some corporate governance mechanisms like board independence and institutional ownership might be positively related with entrepreneurship (and with innovation) (Albu \& Mateescu, 2015). 
There seems to be an agreement on the positive effect of corporate entrepreneurship and innovation on the economic growth and competitive advantage of nations. Therefore, it is crucial "that public policy matters are able to distinguish between supporting entrepreneurial activity versus merely supporting small- and medium-sized enterprises" (Cumming \& Chakrabarti, 2014). Additionally, it is important to understand how public governance and corporate governance efficiently work and intersect to enable entrepreneurial activity.

\subsection{The governance of unlversltles}

As any corporation, a university also deals with decision-making, stakeholders' interests, financing issues and other governance issues typical of a firm. Moreover, the governance of universities has an impact on their third mission (Göransson \& Brundenius, 2011), related to innovation and regional development. On one side, the governance of higher education institutions might be crucial to define its orientation towards a third mission vision or a more traditional one, as well as to identify the willingness to collaborate with external entities such as firms and public institutions. In a previous section, the governance of innovation was mentioned in the case of firms and regions and in the case of private and public institutions; it is also very relevant at the university level. Knowledge transfer activities and university-industry interaction have become a strategic issue for universities as these are sources of funding and a policy tool for economic development (Geuna \& Muscio, 2009).

As for firms, universities' performance and governance can be examined in useful ways (Aghion et al., 2010). There are different governance features that can be analysed in a university, such as ownership/control structure and concentration (public vs private), board composition, autonomy and accountability, interests of stakeholders (students, professors, employees, directors, investors, etc.), financing/funding issues and monitoring/auditing activities, among other matters that are relevant for the performance of universities and their relationships with firms and regions. 


\section{Conclusion}

This short paper is an attempt to generate bridges between corporate governance and innovation for future research. Four general bridges have been mentioned: 1) the governance of innovation, 2) innovation in governance, 3) corporate governance and entrepreneurship and 4) the governance of universities. These research opportunities have been presented in an exploratory and introductory way, as this work is also an invitation to visit more novel and relevant/useful issues rather than to go on revisiting sufficiently explored topics in social science.

\section{Acknowledgements}

PhD Funding: The author is a PhD fellow of RUNIN project, a European Training Network for Early-Stage Researchers, funded by EU's Horizon 2020 Research and Innovation Programme under Marie Skłodowska-Curie grant Agreement \# 722295.

Summer School Organizers: The summer school this paper was prepared for took place in University of Ljubljana, Slovenia, in the framework of the project "Corporate Governance and European Union Integration", supported by the Jean Monnet Network action of the Erasmus + Programme of the European Union.

\section{References}

Aghion, P., Dewatripont, M., Hoxby, C., Mas-Colell, A., \& Sapir, A. (2010). The governance and performance of universities: evidence from Europe and the US. Economic Policy (61), 7-59.

Albu, N., \& Mateescu, R. (2015). The relationship between entrepreneurship and corporate governance: the case of Romanian listed companies. Amfiteatru Economic, 17(38), 44-59.

Arnkil, R., Järvensivu, A., Koski, P., \& Piirainen, T. (2010). Exploring the quadruple helix. Report of quadruple helix research for the CLIQ project. Tampere: Work Research Centre. University of Tampere.

Cadbury, A. (1992). Report of the Committee on the Financial Aspects of Corporate Governance. London: Gee. Professional Publishing Ltd. 
Charles, D. (2006). Universities as key knowledge infrastructures in regional innovation systems. Innovation: the European journal of social science research, 19(1), 117-130.

Cohen, W., \& Levinthal, D. (1990). Absorptive Capacity: A New Perspective on Learning and Innovation. Administrative Science Quarterly, 35(1), 128-152.

Cooke, P., Uranga, M., \& Etxebarria, G. (1997). Regional innovation systems: institutional and organizational dimensions. Research Policy, 26, 475-491.

Cumming, D., \& Chakrabarti, R. (2014). Global Perspectives on Entrepreneurship: Public and Corporate Governance. Corporate Governance. An International Review, 22(2), 73-76. DOI: $10.1111 /$ corg.12061

European Commission. (2017). Horizon 2020: The EU Framework Programme for Research and Innovation. Retrieved July 2017, from https://ec.europa.eu/programmes/horizon2020/

Fonseca, L., \& Cinar, R. (2017). Engaged and Innovative Universities in LessDeveloped Regions: The Case of the University of Aveiro. Presented at the 12th Regional Innovation Policies Conference, Santiago de Compostela, October $26^{\text {th }}$ $27^{\text {th }}$ 2017. RUNIN Project Working Paper Series, 2017(1), 1-20.

Geuna, A., \& Muscio, A. (2009). The Governance of University Knowledge Transfer: A Critical Review of the Literature. Minerva, 47(1), 93-114. DOI: 10.1007/s11024009-9118-2

Goergen, M. (2012). Internationa/ Corporate Governance. Harlow, England: Pearson Education Limited.

Gompers, P., Ishii, J., \& Metrick, A. (2003). Corporate Governance and Equity Prices. Quarterly Journal of Economics, 118(1), 107-155. DOI: $10.1162 / 00335530360535162$

Göransson, B., \& Brundenius, C. (2011). Universities in Transition: The Changing Role and Challenges for Academic Institutions. Ottawa, Canada: Springer. International Development Research Centre.

Heidenreich, M., \& Koschatzky, K. (2011). Regional Innovation Governance. In P. Cooke, B. Asheim, R. Boschma, R. Martin, D. Schwartz, \& F. Tödtling, Handbook of 
Regional Innovation and Growth. Edward Elgar Publishing. DOI: $10.4337 / 9780857931504.00061$

Hitt, M., Hoskisson, R., Johnson, R., \& Moesel, D. (1996). The market for corporate control and firm innovation. Academy of Management Journal, 39(5), 1084-1119. DOI: $10.2307 / 256993$

Hoskisson, R., Hitt, M., Johnson, R., \& Grossman, W. (2002). Conflicting voices: The effects of institutional ownership heterogeneity and internal governance on corporate innovation strategies. Academy of Management Journal, 45(4), 697-716. DOI: $10.2307 / 3069305$

La Porta, R., Lopez-de-Silanes, F., Shleifer, A., \& Vishny, R. (1998). Law and Finance. Journal of Political Economy, 106(6), 1113-1155.

Manrique, S. (2018). The Impact of University-Firm Collaboration on Firm Performance and Regional Development: The Case of UAB and Barcelona Region. Presented at the $5^{\text {th }}$ Master Class on EU Cohesion Policy - $15^{\text {th }}$ European Week of Regions and Cities, Brussels, October $8^{\text {th }}-12^{\text {th }}$ 2017. RUNIN Project Working Paper Series, 2018(8), 1-17.

Manrique, S., \& Nguyen, H. T. (2017). Balancing Regional Engagement and Internationalisation: The Case of Autonomous University of Barcelona. Presented at the 12th Regional Innovation Policies Conference, Santiago de Compostela, October $26^{\text {th }}-27^{\text {th }}$ 2017. RUNIN Project Working Paper Series, 2017(2), 1-25.

Moore, M., \& Hartley, J. (2008). Innovations in Governance. Public Management Review, 10(1), 3-20. DOI: 10.1080/14719030701763161

Morck, R., Wolfenzon, D., \& Yeung, B. (2005). Corporate governance, economic entrenchment, and growth. Journal of Economic Literature, 43(3), 655-720. DOI: $10.1257 / 002205105774431252$

Nieth, L., Benneworth, P., Charles, D., Fonseca, L., Rodrigues, C., Salomaa, M., \& Stienstra, M. (2017). Embedding Entrepreneurial Regional Innovation Ecosystems: Reflecting on the Role of Effectual Entrepreneurial Discovery Process. RUNIN Project Working Paper Series, 2018(6), 1-33.

OECD. (2004). OECD Principles of Corporate Governance. Paris: Organisation for Economic Cooperation and Development. 
Perkmann, M., \& Walsh, K. (2007). University-industry relationships and open innovation: Towards a research agenda. Journal of Management Review, 9(4), 259280.

Shleifer, A., \& Vishny, R. (1997). A Survey of Corporate Governance. Journal of Finance, 57(2), 737-783. DOI: 10.1111/j.1540-6261.1997.tb04820.x

Swyngedouw, E. (2005). Governance innovation and the citizen: The Janus face of governance-beyond-the-state. Urban Studies, 42(11), 1991-2006. DOI: $10.1080 / 00420980500279869$

Teece, D. J. (1986). Profiting from technological innovation: Implications for integration, collaboration, licensing and public policy. Research Policy, 15(6), 285305. DOI: 10.1016/0048-7333(86)90027-2

Tsui, A. S. (2013). The Spirit of Science and Socially Responsible Scholarship. Management and Organization Review, 9(3), 375-394. DOI: 10.1111/more.12035

Tylecote, A. (2007). The role of finance and corporate governance in national systems of innovation. Organization Studies, 28(10), 1461-1481. DOI: $10.1177 / 0170840607075676$

Yoshikawa, T., Tsui-Auch, L., \& McGuire, J. (2007). Corporate governance reform as institutional innovation: The case of Japan. Organization Science, 18(6), 973-988. DOI: 10.1287 /orsc. 1070.0290

Zahra, S. (1996). Governance, ownership, and corporate entrepreneurship: The moderating impact of industry technological opportunities. Academy of Management Journal, 39(6), 1713-1735. DOI: 10.2307/257076 